\title{
Economic Opportunities Resulting From a Global Deployment of Concentrated Solar Power (CSP) Technologies - The Example of German Technology Providers
}

Originally published as:

Daniel Vallentin, Peter Viebahn (2010):

Economic Opportunities Resulting From a Global Deployment of Concentrated Solar Power (CSP) Technologies - The Example of German Technology Providers In: Energy Policy 38(8) 4467-4478 
Daniel Vallentin ${ }^{a,{ }^{*}}$, Peter Viebahn ${ }^{a}$

Economic Opportunities Resulting

From a Global Deployment of

Concentrated Solar Power (CSP)

Technologies - The Example of

German Technology Providers

a Wuppertal Institute for Climate, Environment and Energy, Germany

*Corresponding author: Daniel Vallentin, Wuppertal Institute, Neue Promenade 6, 10178 Berlin, Germany

E-mail: daniel.vallentin@wupperinst.org

Phone: $+49-030-2887458-12$

Fax: $\quad+49-030-2887458-40$ 


\begin{abstract}
Several energy scenario studies consider concentrated solar power (CSP) plants as an important technology option to reduce the world's $\mathrm{CO}_{2}$ emissions to a level required for not letting the global average temperature exceed a threshold of $2-2.4^{\circ} \mathrm{C}$. A global ramp up of CSP technologies offers great economic opportunities for technology providers as CSP technologies include highly specialised components. This paper analyses possible value creation effects resulting from a global deployment of CSP until 2050 as projected in scenarios of the International Energy Agency (IEA) and Greenpeace International. The analysis focuses on the economic opportunities of German technology providers since companies such as Schott Solar, Flabeg or Solar Millenium are among the leading suppliers of CSP technologies on the global market.
\end{abstract}

Keywords: Concentrating Solar Power; Value Chain; German Companies

\title{
1. Introduction
}

\subsection{Background}

Mitigating carbon emissions from fossil-fired power plants is discussed intensively on a global scale. In order to let the global average temperature not exceed a threshold of $2-2.4^{\circ} \mathrm{C}$ as defined by the Intergovernmental Panel on Climate Change (IPCC), a global greenhouse gas emissions reduction by $50-85 \%$ until 2050 compared to the level of 2000 is mandatory (IPCC 2007).

Several energy scenario studies consider concentrated solar power (CSP) plants, as an important technology option to meet this target. According to the International Energy Agency (IEA), approximately $11 \%(4,754 \mathrm{TWh})$ of the global electricity demand until 2050 need to be covered by solar energy. Besides photovoltaic panels, CSP plants are estimated to produce about $46 \%$ (ca. 2,200 TWh) of the projected amount of solar power (IEA, 2008). The Energy (R)Evolution scenario of Greenpeace International and EREC (European Renewable Energy Council) quantifies the contribution of CSP to global power demand at approximately $6,000 \mathrm{TWh}$ in 2050 with an installed generating capacity of $801 \mathrm{GW}$ (Greenpeace International and EREC, 2008).

CSP plants bundle solar radiation using concentrating mirrors. The concentrated radiation is then transformed into thermal energy and used to power conventional steam and gas turbines or stirling engines. CSP makes it possible to offer „power on demand“ via heat storage and will be of particular interest for generation units between 200 and $400 \mathrm{MW}_{\mathrm{el}}$. It works as a regenerative alternative to conventional power generation technologies both for base load and peak load as well as for balancing varying power supply from wind and photovoltaic. Apart from producing electricity, the process heat emitted by CSP may be used to cool buildings and industrial processes, production of hydrogen or operation of facilities for the desalination of sea water.

The global market spread of CSP technologies is fostered by several initiatives, both internationally and in Germany:

DESERTEC Foundation: The foundation's creation was supported by the German chapter of the Club of Rome and the Trans-Mediterranean Renewable Energy Cooperation (TREC). It was founded in early 2009 and promotes a vision for achieving a global power system by 2050 which is substantially based on renewable power generated in the deserts of the Middle 
East and North Africa (MENA). About 5,000 GW of CSP capacities shall be installed by 2050 , covering $0.3 \%$ of the world's desert areas with solar mirrors (Knies, 2009).

DESERTEC Industrial Initiative: On October $30^{\text {th }}$, the DESERTEC Foundation and Munich Re together with a group of European companies, including major players such as Siemens, RWE, Schott Solar or Deutsche Bank, established the DESERTEC Industrial Initiative (DII) in Munich to accelerate the implementation of the DESERTEC concept. By 2050, CSP plants located in the MENA region shall satisfy a substantial part of the energy needs of the MENA countries and meet as much as $15 \%$ of Europe's electricity demand.

Mediterranean Solar Plan: Initiated by the French President Nicolas Sarkozy, the Mediterranean Union was established in summer 2008. The Union encompasses 43 members, including the EU member states and countries of the Mediterranean region. The Union has set up a "Mediterranean Solar Plan" which aims at erecting $20 \mathrm{GW}$ of renewable-based power generating capacity in the Southern Mediterranean region by 2020. CSP plants shall contribute 10-12 GW to this objective. Besides CSP, the Solar Plan fosters the deployment of other renewable energy technologies, such as wind power (5-6 GW) or photovoltaic (3-4 $\mathrm{GW}$ ). Some of the produced electricity shall be transmitted to the European Union via highvoltage lines.

Activities of the German government: The German federal government has fostered the inclusion of CSP technologies as an integral part of the activities of the Mediterranean Union. The government is providing research and development (R\&D) funding for CSP technologies since 1976. From 2005 to 2008, the average annual funding for CSP totalled $€ 6$ million per year. This is equivalent to approximately $7 \%$ of the total R\&D budget for renewable energy technologies (Christmann, 2009).

European Union's legislation: The European Union made an important step towards the use of electricity from CSP sources within the European market when it passed the Renewable Energy Directive as part of the "green package" in June 2009. This directive allows its Member States to import "electricity from renewable energy sources" from third countries for the purposes of measuring compliance with the requirements of national overall renewable energy targets. In this case, the imported electricity will have to be produced by newly constructed installations that became operational after the Directive entered into force or by the increased capacity of an installation that was refurbished after the Directive entered into force. Construction for high-voltage direct-current transmission installations (HVDC) must start before December 31, 2016, and the interconnection must be operative before December 31, 2022 (EU, 2009).

\subsection{Research Question}

The export or transfer of CSP technologies to the MENA regions offers great economic opportunities for technology providers as CSP technologies include highly specialised components, such as absorber technologies or heat transfer fluids. In the following, economic opportunities entailing from the export of CSP technologies shall be analysed by the example of German technology providers. German technology providers were selected as a case study for this paper since technology companies such as Schott Solar, Flabeg or Solar Millenium are among the leading suppliers of CSP technologies on the global market. The article scrutinises to which degree a global deployment of CSP until 2050 would generate added value for the German industry.

The study is composed as follows: Section 2 gives a brief introduction on the most important CSP technology options and their current status of development and deployment. Section 3 analyses the current fields of expertise of German technology providers and their international market position. Section 4 defines the share of German companies in the valued added chain 
of a reference CSP plant and projects their economic benefits from a global spread of CSP based on three technology deployment scenarios. Section 5 draws conclusions from the previous analysis and outlines starting points for further studies.

\section{Status of CSP Technology and Deployment}

At present, the international discourse on CSP focuses on two technology options: parabolic trough technologies and solar tower technologies. Other technology paths, such as dish stirling systems or Fresnel collector systems, are less mature and, therefore, currently not at the centre of the debate.

\section{Figure 1 Different CSP Technology Options (Geyer and Mancini, 2006)}

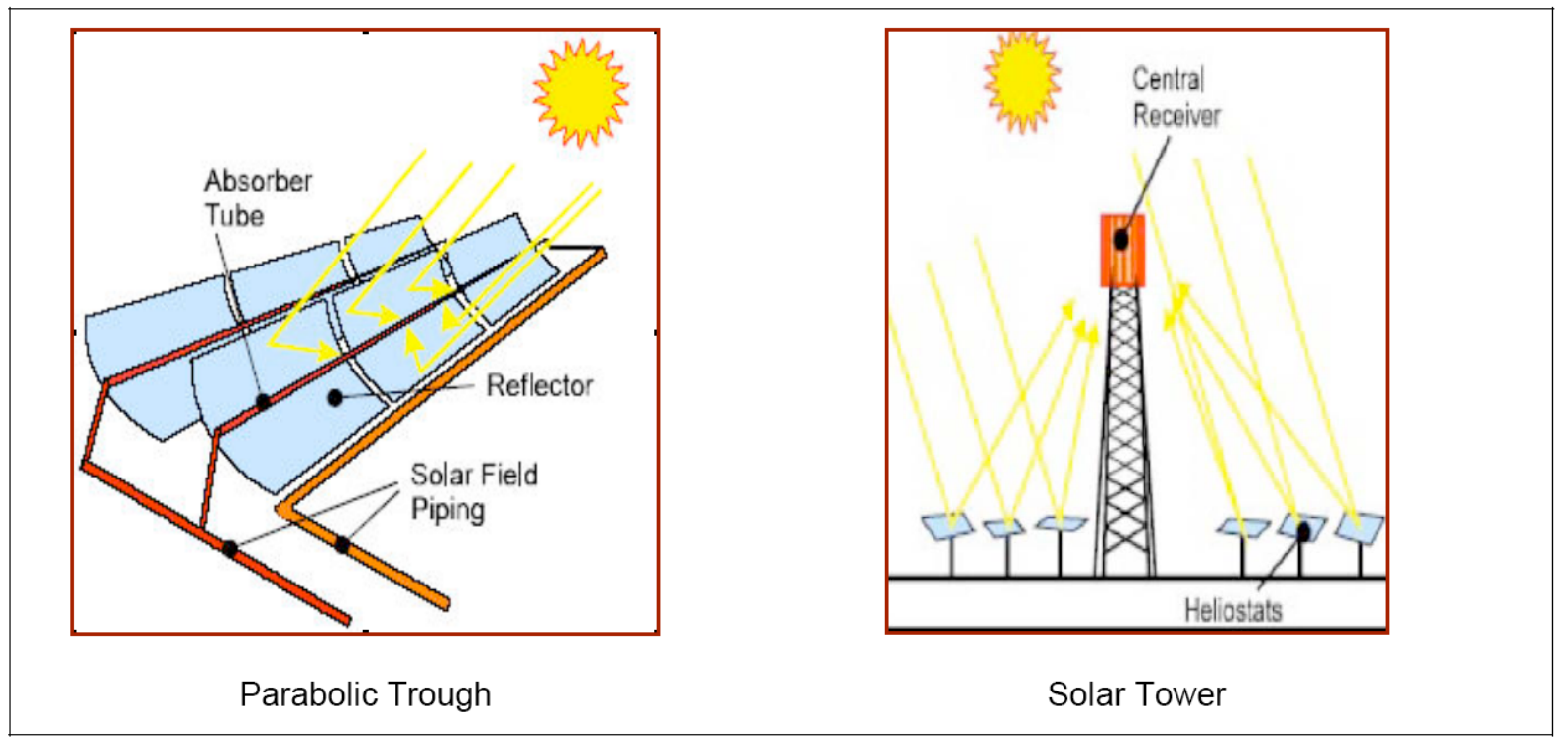

\subsection{Parabolic Trough Technology}

Parabolic trough technology is the most mature and economic solar thermal power generation technology today. Solar radiation is concentrated by parabolically curved, trough-shaped reflectors onto a receiver pipe running along the inside of the curved surface. Within the pipe, the solar energy heats up a heat transfer medium (e.g. oils, molten salt) to approximately $400^{\circ} \mathrm{C}$. The medium transfers the heat to a power block where it is used to generate electricity in a conventional steam generator. The average operating efficiency of parabolic trough plants ranges from 9-14\% (Viebahn et al., 2008). The rather low efficiency is due to the limited heating capacity of available heat transfer fluids which is why the development of more efficient fluids is subject of several R\&D projects.

In the 1980s, nine commercial-scale parabolic trough plants named "Solar Electricity Generating Systems (SEGS)" with a total capacity of $354 \mathrm{MW}_{\mathrm{el}}$ were erected in California, being the world's first large-scale facilities of their kind. In 2006, the first new parabolic trough plant $\left(1 \mathrm{MW}_{\mathrm{el}}\right)$ since the SEGS plants started operation in the United States. In spring 2007, another facility ("Nevada Solar One") with a capacity of $64 \mathrm{MW}_{\mathrm{el}}$ was commissioned in Nevada, U.S. Currently in the United States nearly 1,700 $\mathrm{MW}_{\mathrm{el}}$ of parabolic trough capacities are planned (based on own database).

In Spain, parabolic trough plants $\left(50 \mathrm{MW}_{\mathrm{el}}\right.$ each) with a total capacity of $350 \mathrm{MW}_{\mathrm{el}}$ are presently under construction. Test runs of a $50 \mathrm{MW}_{\mathrm{el}}$ facility, known as Andasol I and operated by the German company Solar Millennium, have been completed recently. Andasol 
II and Andasol III, also with a load of $50 \mathrm{MW}_{\mathrm{el}}$, are under construction or in the planning process, respectively - as several other power plants of Spanish companies. Integrated Solar Combined Cycle (ISCC) plants which use natural gas as a back-up and produce power in a combined cycle process are being constructed in Algeria, Morocco and Egypt. Their solar capacity cumulates to $60 \mathrm{MW}_{\mathrm{el}}$. The worldwide capacity of planned parabolic trough plants sums up to 3,654 $\mathrm{MW}_{\mathrm{el}}$ (based on own database).

\subsection{Solar Tower Technology}

Solar tower technology utilises numerous large sun-tracking mirrors (heliostats) to focus sunlight on a receiver at the top of a tower. A heat transfer fluid heated in the receiver which is heated up to temperatures of $500-1,000^{\circ} \mathrm{C}$ is used for steam generation. The steam is then fed to a conventional turbine generator to produce electricity. Steam, molten salt or air may be used as heat transfer media. Since heat transfer is limited to one point of the process, solar tower systems are less energy intensive than parabolic through technologies. Their overall efficiency ranges from 13 to $18 \%$ (Viebahn et al., 2008). The development of more efficient heat transfer fluids could raise efficiency by approximately 20\% (ESTELA, 2009).

At the time being, there are merely few solar tower plants in operation. The first new solar tower plant named "PS10" has a capacity of $10 \mathrm{MW}_{\mathrm{el}}$ and is situated in the province of Sevilla, Spain. It is operated by Abengoa, a Spanish technology provider, and is online since 2007. The plant comprises a thermal storage with a capacity of $20 \mathrm{MW}_{\text {th }}$. On the same site, a $20 \mathrm{MW}_{\mathrm{el}}$ solar tower plant ("PS 20") started operation in April 2009. Torresol is currently constructing another plant $\left(17 \mathrm{MW}_{\mathrm{el}}\right)$ in Sevilla. $60 \%$ of Torresol are in the hands of Masdar, Abu Dhabi's initiative for renewable energy; $40 \%$ are owned by Sener, a Spanish engineering company.

In Germany, a $1.5 \mathrm{MW}_{\mathrm{el}}$ demonstration plant was put into operation in mid 2009. The project is funded by the local power utility of Jülich in North Rhine-Westphalia (NRW) and was mainly realised by Kraftanlagen München (KAM). The project shall function as a stimulus for technology export.

Globally, the capacity of planned solar tower plants sums up to $935 \mathrm{MW}_{\mathrm{el}}$.

\subsection{Other CSP Options}

Other CSP technology paths are Fresnel collectors and dish stirling systems. In contrast to the parabolic trough technology, Fresnel plants consist of flat, parallel-arranged mirrors, which concentrate the solar radiation on an absorber beyond the collector field. The arrangement of the collectors requires about two thirds less space than a parabolic trough field with the same generating capacity. Due to their lightweight structure they require much less construction materials than parabolic troughs. This leads to a land-use reduction by $50 \%$, referring to the output of $1 \mathrm{kWh}_{\mathrm{el}}$ (Viebahn et al. 2008). However, the operating efficiency of Fresnel collectors is approximately one third below the efficiency of parabolic trough technologies. The technology is at an early stage of demonstration. In the United States, a $5 \mathrm{MW}_{\mathrm{el}}$ Fresnel plant is under construction; a $1.4 \mathrm{MW}_{\text {el }}$ plant was commissioned in Murcia, Spain, in March 2009. The $18,000 \mathrm{~m}^{2}$ collector field of this facility was supplied by the German company Novatec Biosol (Selig, 2009).

Dish stirling systems are preferably used for smaller generating units with capacities ranging from 5 to $50 \mathrm{~kW}$ (BINE 2003). However, stand-alone generating systems can be connected to a CSP park. Parabolic dish systems consist of a parabolic-shaped point focus concentrator which has the shape of a dish. The point focus reflects solar radiation onto a receiver mounted at the focal point. The receiver absorbs the radiation and transfers it in the form of hightemperature heat (up to $1,200^{\circ} \mathrm{C}$ ) to the stirling engine which is connected to a generator. The technology has an efficiency of $15-24 \%$ and is the most efficient CSP technology path. 
However, despite ongoing R\&D activities, no large-scale plant is operating yet. A $0.15 \mathrm{MW}_{\mathrm{el}}$ pilot plant started operation in Albuquerque, U.S., in 2005. At the end of 2009, a $1.5 \mathrm{MW}_{\mathrm{el}}$ facility is scheduled for completion in Arizona, U.S., in California. Two large-scale plants with a total start-up capacity of $800 \mathrm{MW}_{\mathrm{el}}$ are being developed (SES, 2009).

Figures 2 and 3 illustrate the total capacities of operating CSP plants, plants under construction and planned facilities by country and technology. Sarasin (2009) estimates that CSP capacities operating in 2008 (approximately $485 \mathrm{MW}_{\mathrm{el}}$ ) cumulated to an overall investment volume of $€ 2.2$ billion. The figures clearly show that the parabolic through technology is and will remain the most widely applied CSP technology. Spain and the United States currently function as CSP pioneer markets and accommodate most of the plants that are currently at the planning stage.

Figure 2 CSP Plants Worldwide by Country (Own Calculation)

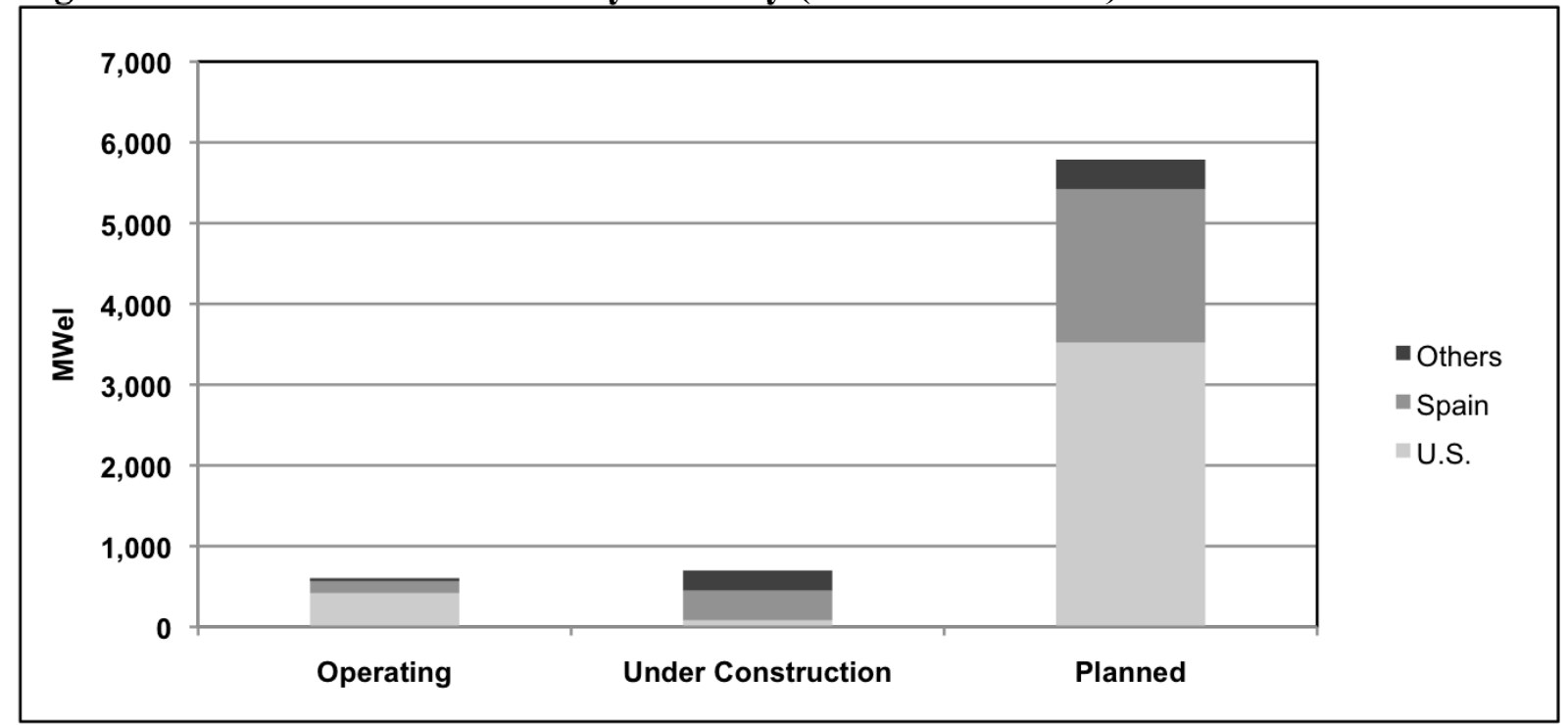

Figure 3 CSP Plants Worldwide by Technology (Own Calculation)

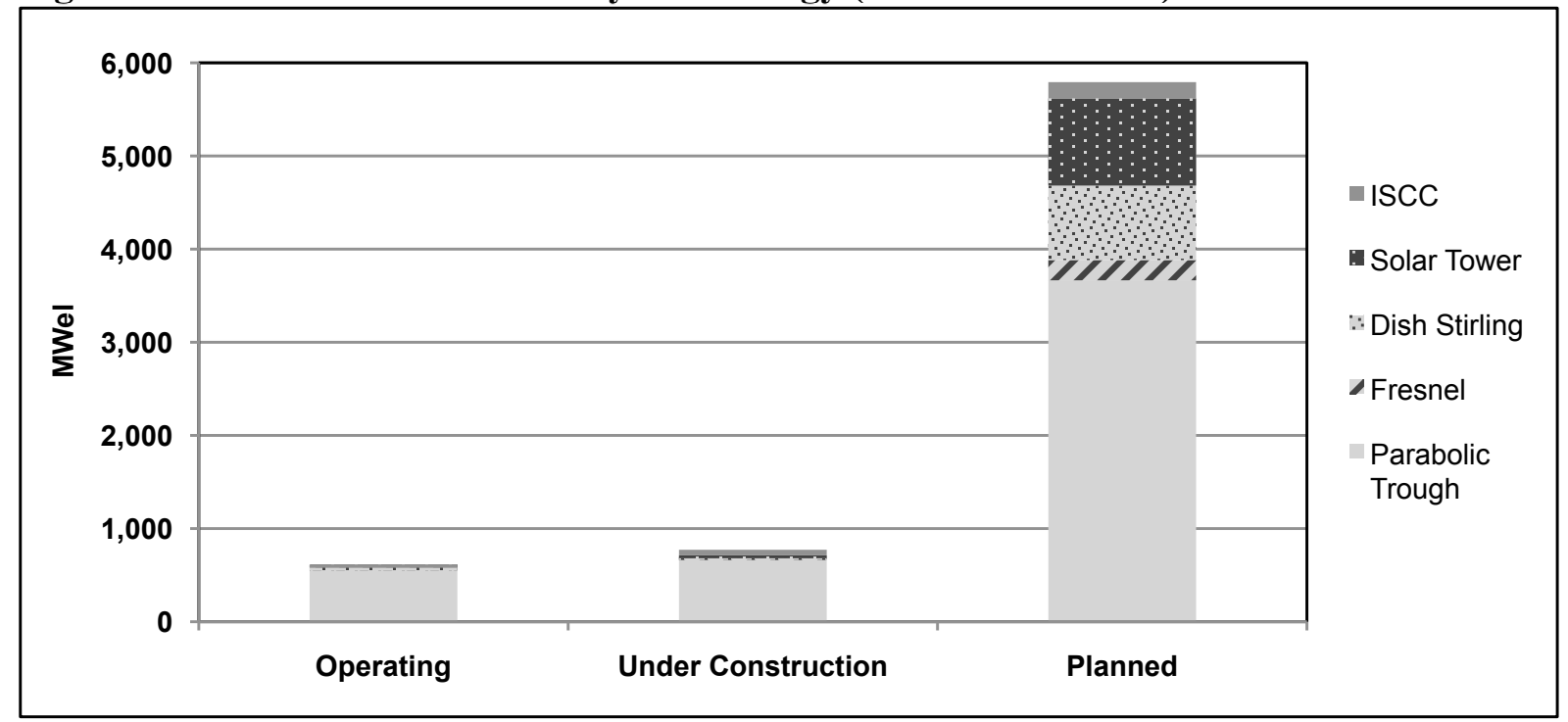




\section{Activities and Market Position of German Technology Companies along the Value-Added Chain of CSP}

German technology companies have a prominent market position at all stages of the valueadded chain of CSP technologies, including engineering and services, manufacturing and supply of plant components as well as realisation and operation of CSP plants.

Table 1 presents an overview of important German technology companies which are active at the different stages of the CSP value-added chain.

Table 1 German Technology Companies on the Field of CSP (Own Collection)

\begin{tabular}{|l|l|}
\hline Expertise & Company \\
\hline Engineering \& Services & \\
\hline & Schlaich Bergmann \\
& Fichtner Solar \\
& CSP Services \\
\hline Component Suppliers & Schott Solar \\
\hline Flagsol GmbH \\
Solar Power Group \\
Flabeg Holding GmbH \\
Siemens AG \\
\hline Züblin AG \\
Senior Berghöfer \\
Linde AG \\
\hline
\end{tabular}




\subsection{Engineering \& Services}

The most prominent companies active on this field are Schlaich Bergermann Partner (SBP) and Fichtner Solar. Both companies are well-established market players with rich practical experiences and references. SBP was involved in the development and planning of parabolic plants in Spain (Andasol I-III), Egypt and the United States and contributed to the development of some small-scale dish-stirling units. Fichtner Solar works since more than 25 years on CSP technologies and possesses a worldwide network of offices or subsidiaries which may be activated for CSP projects. It is among the world's leading engineering companies for CSP. So far, Fichtner has been involved in CSP projects (including ongoing projects) with an overall financial volume of about $€ 5$ billion. Among these projects are ISCC plants in Egypt, India and Morocco. A rather new market player is CSP Services (CSPS). The company promotes the know-how and equipment (e.g. quality control systems, optimisation of collector fields) of the German Aerospace Centre (DLR) which has a long research tradition on CSP. CSPS is a small company with 14 employees who also belong to DLR. The company strongly benefits from DLR's expertise and international reputation.

\subsection{Component Suppliers}

German component manufacturers like Schott Solar, Flabeg or Siemens are among the leading technology providers worldwide. The production and supply of highly specialised and technically complex components for CSP plants is the stage of the CSP value-added chain where German companies are most strongly represented. According to Kistner (2009), the participation of German companies in the global value-added chain of CSP could be significantly increased if the German industry would further expand its know-how on strategically important fields, such as turbines or solar fields.

The activities of the German industry comprise nearly all stages of CSP processes. Schott Solar is the world's leading supplier of receiver technologies for parabolic trough plants. Schott's technology is, among other projects, being applied in the Andasol I and Nevada Solar One plants. The company has signed contracts for all CSP key markets, such as the United States, Southern Europe or the Middle East, and expects a significant growth of turnover in the coming business year (Schott, 2008).

The Flabeg Group manufactures highly developed solar reflector technologies for CSP plants. Since the 1980s, Flabeg has supplied solar mirrors to literally all existing CSP facilities and those being under construction. In total, Flagbeg has been involved in CSP projects with a capacity of about 1.3 GW (Flabeg, 2009).

Other important market players which are based in Germany are Flagsol, Senior Berghöfer, Züblin or Siemens. Flagsol is a $100 \%$ subsidiary of Solar Millennium, a major German general contractor for CSP plants, and has supplied key components (e.g. collectors, solar field control systems) to several existing CSP plants. Senior Berghöfer is a leading supplier of expansion joints, control bellows or hoses which, for example, are needed to connect the elements of a receiver. Züblin, a building company, is a new player on the CSP market. It has formed a small team to develop concrete heat storages. Presently, Züblin is developing a pilot module for concrete storage in Spain. The renewable energy section of Siemens Energy offers a steam turbine design (SST-700 Dual-Casing Reheat/DRH) which can be operated in CSP plants with capacities of up to $175 \mathrm{MW}_{\mathrm{el}}$. By September 2008, Siemens had received more than 40 orders for solar thermal steam turbines. Among the planned projects, 38 are located in Spain, three in the United States and one each in Algeria and Egypt (Siemens, 2008). Siemens expects the CSP market to grow by $20 \%$ per year until 2020 and therefore has significantly increased its manufacturing capacities for solar thermal steam turbines recently. By acquiring Solel Solar Systems in October 2009, Siemens has, furthermore, expanded its CSP product 
portfolio to solar receivers and engineering of the solar field (Siemens AG Energy Sector 2009).

\subsection{General Contractors}

German general contractors for the realisation of CSP projects include MAN Ferrostaal ${ }^{1}$, Solar Millennium, Kraftanlagen München and Novatec Biosol. Solar Millennium indicates the highest involvement of German players in planned CSP plants at the international level. However, the international market is dominated by Spanish companies, such as Abengoa Solar, Solel, Aries or Iberdrola. In the United States, BrightSource Energy plays an important role (see figure 4). Market competition is expected to increase in the coming years since nonrenewable market players are pushing into the CSP market. For example, in March 2010 AREVA, the leading U.S. nuclear vendor, announced the acquisition of. U.S.-based Ausra Inc., a provider of CSP technologies for power generation and industrial steam production (Ausra. 2010).

\section{Figure 4 CSP Plants Worldwide by Implementing General Contractors (Own Calculation)}

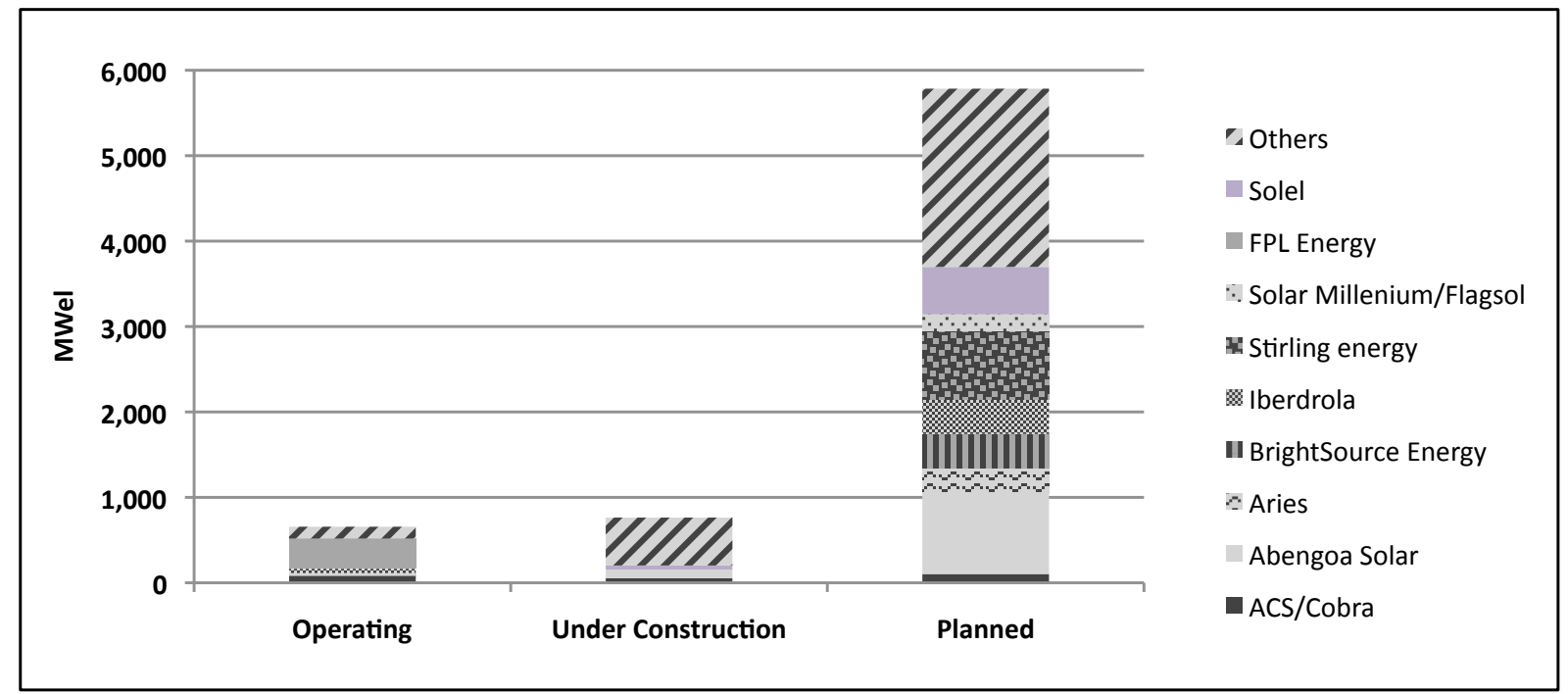

Solar Millennium has developed the Andasol I and II plants in Spain and is active on all stages of the CSP value-added chain. It has formed a 50-50 joint venture with MAN Ferrostaal, MAN Solar Millennium, for the realisation of CSP plants. The company has subsidiaries in the United States, holds shares in regional project developing companies in Spain and China and owns 100\% of the technology company Flagsol.

MAN Ferrostaal's CSP activities are managed by MAN Solar Millennium and the Solar Power Group. While the former focuses on parabolic trough plants, the latter is promoting a Fresnel collector system with MAN Ferrostaal holding about $43 \%$ of the company's shares. MAN Ferrostaal is involved in the development, management and operation of CSP plant projects. Kraftanlagen München and Novatec Biosol AG are rather small general contractors with a limited number of reference projects. As mentioned above, KAM is involved in the Jülich solar tower demonstration plant. Presently, it participates in a feasibility study for a 5$10 \mathrm{MW}_{\mathrm{el}}$ solar tower plant in Algeria. Novatec Biosol produces and markets a Fresnel collector system named "Nova-1" and offers support for the integration of the solar field. In

1 In November, 2009, the International Petroleum Investment Company (IPIC) from Abu Dhabi took over the majority of shares in MAN Ferrostaal. According to the company, it plans to change its name from "MAN Ferrostaal" to "Ferrostaal". 
March 2009, the 1.4 $\mathrm{MW}_{\mathrm{el}}$ demonstration plant Puerto Errado (PE-1), which is situated Southern Spain and applies the Nova-1 technology, started operation.

\section{German Participation in the Value-Added Chain of CSP}

\subsection{Methodology}

In order to define the possible German share in the value created as a result of the global deployment of the CSP technology in the future, this paper uses the methodology of scenario analysis and combines three different types of scenarios:

Technology deployment scenarios: For a quantification of the global market potential of CSP technologies, a reference scenario and two more ecologically oriented scenarios are used as a basis. As a reference scenario, the IEA reference scenario from the 2007 World Energy Outlook was selected; it is supplemented by a "moderate" and an "ambitious" deployment scenario from a recently published Greenpeace report (Greenpeace International et al., 2009). The scenarios make assumptions about the global expansion of CSP generating capacities until 2050.

Cost scenarios for CSP key components: In a second step, the paper analyses the cost development of CSP key components until 2050 applying the learning curve approach. For this aim, a parabolic trough plant which has been investigated by from MAN Ferrostaal (Kistner, 2009) is used as a reference plant (see section 4.2). Afterwards, CSP learning curves developed by Viebahn et al. (2008) are used to calculate the cost development of key components such as the solar field, thermal energy storage and the power block until 2050.

The learning ratio of a technology indicates at which percentage investment costs decrease if the globally installed capacity of the concerned technology doubles. For example, a learning ratio of $15 \%$ implies that costs decline by $15 \%$ if capacity is doubled. Based on the learning ratio, the progress ratio defines the remaining costs. At a learning ratio of $15 \%$, the progress ratio is $85 \%$.

Learning curves are calculated as follows: The investment costs $c_{x}$ at the time $x$ are derived from the initial costs $c_{o}$ as well as the capacities $p_{x}$ and $p_{0}$. The latter are installed at the time $x$ and the beginning of the learning curve. These parameters are summarised in the following formula:

Figure 5 Formula for Calculating Learning Curves (Neij, et al., 2003)

$$
c_{x}=c_{0} \cdot\left(\frac{P_{x}}{P_{0}}\right)^{\frac{\log P R}{\log 2}}
$$

In our case, the worldwide installed capacity is taken from the technology deployment scenarios, thus resulting in three different long-term cost scenarios.

Value creation scenarios: The study defines percentages of the German participation in the value-added chain of the reference plant in order to quantify the economic benefits of German companies resulting from a global CSP deployment. The percentages are quoted from an economic analysis of MAN Ferrostaal (Kistner, 2009). Based on the given percentages and considering both, the CSP deployment scenarios and the cost scenarios, the German share in the resulting value creation is extrapolated to the year 2050. 


\subsection{Reference Plant}

The reference plant used in this study was defined in an economic analysis of MAN Ferrostaal (Kistner, 2009) and is mainly based on cost data of the Andasol III plant (parabolic trough). The construction of Andasol III was kicked off recently; the plant will be realised by MAN Solar Millennium and Sener. The $50 \mathrm{MW}_{\text {el }}$ facility includes a thermal molten-salt storage with a storage capacity of 7.5 hours or $375 \mathrm{kWh}_{\mathrm{el}}$. Plant investment costs are estimated at $€ 300$ million or $€ 6,000 / \mathrm{kW}_{\mathrm{el}}$ considering that this plant will be the first one using direct steam instead of thermooil as heat transfer fluid.

The distribution of investment costs among key CSP components as assumed by Kistner (2009) is shown in figure 6.

Figure 6 Specific Investment Costs of the Reference Plant According to Kistner (2009)

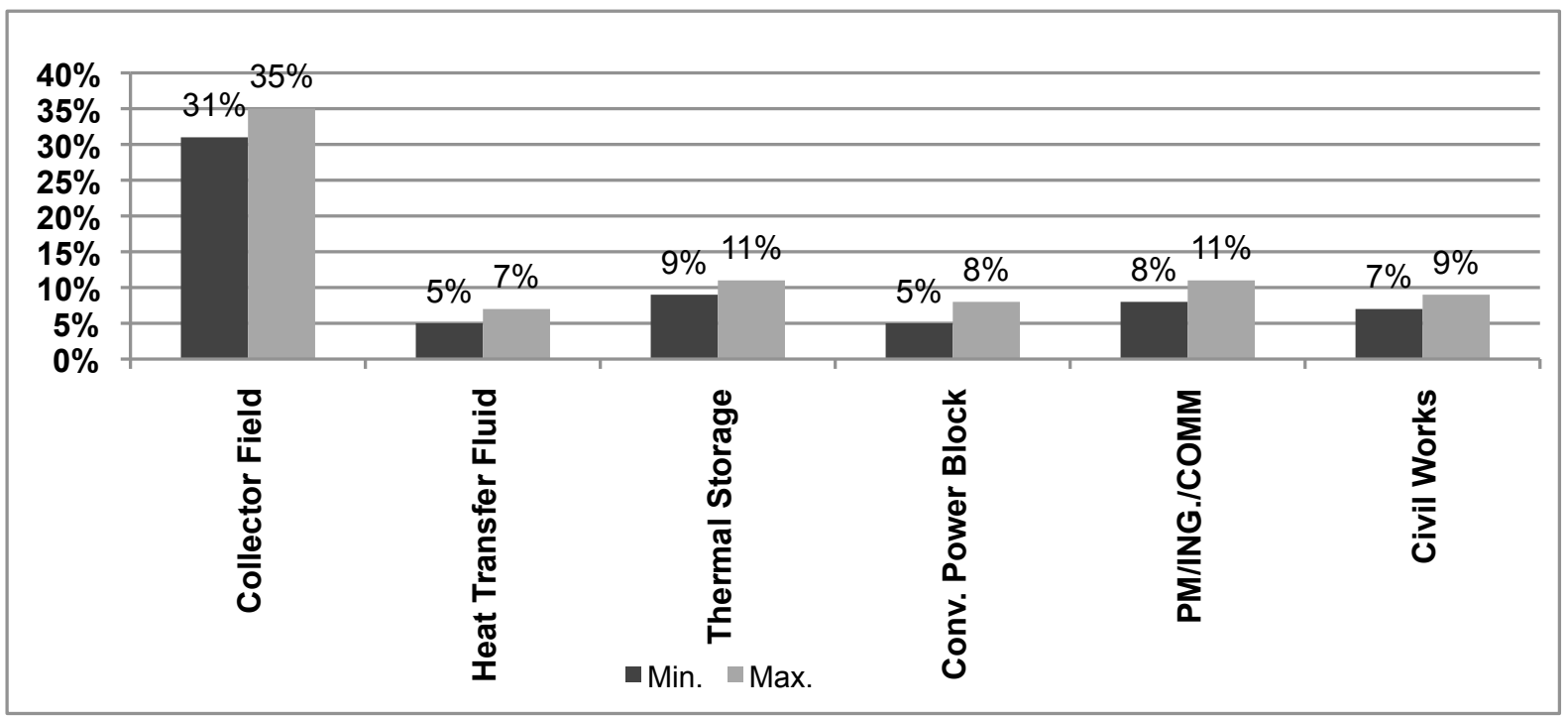

However, this illustration does not reflect $100 \%$ of the plant investment costs, since important cost factors, such as the balance of plant, have been left out. Missing cost factors add up to 19 to $36 \%$ of total investment costs. In order to take into account $100 \%$ of the reference plant costs, the cost distribution among plant components was modified in line with the assumptions of the NEEDS study (Viebahn et al., 2008). The inclusion of missing cost factors also followed Viebahn's approach. The results are listed in table 2.

Table 2 Specific Investment Costs of the Complete Reference Plant in 2009 (Own Calculation)

\begin{tabular}{lcrrr}
\hline Component & $\begin{array}{c}\text { Share of } \\
\text { Costs }\end{array}$ & \multicolumn{2}{c}{ Specific Investment Costs } \\
\hline Collector Field & $\%$ & $€ / \mathbf{k W}_{\mathrm{el}}$ & & $€ /$ Specific Unit \\
Thermal Storage & 46 & 2,740 & 268 & $€ / \mathrm{m}^{2}$ Aperture \\
Conventional Power Block & 13 & 750 & $104 \quad € / \mathrm{kWh}_{\mathrm{el}}$ Storage Capacity \\
Labour, Commissioning etc. & 19 & 1,130 & $1,140 \quad € / \mathrm{kW}_{\mathrm{el}}$ Capacity \\
\hline Total & 23 & 1,380 & 1,380 & $€ / \mathrm{kW}_{\mathrm{el}}$ Capacity \\
\hline
\end{tabular}

\subsection{Global CSP Deployment Scenarios}

Figure 7 illustrates the IEA reference scenario as well as the CSP deployment paths projected in the "moderate" and "ambitious" scenarios of Greenpeace. 
Figure 7 Scenarios for a Global Deployment of CSP (Greenpeace et al., 2009)

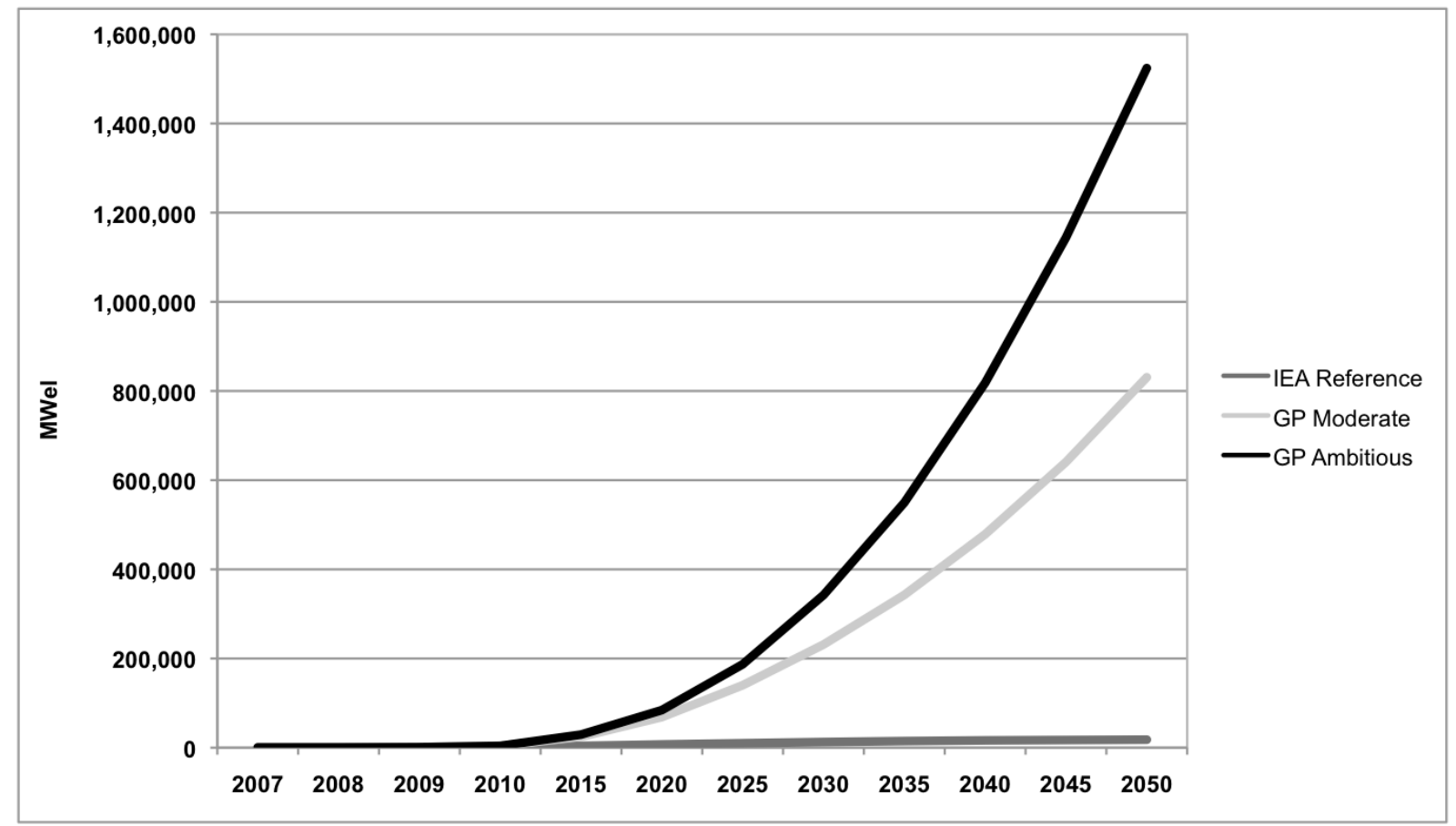

The IEA reference scenario merely takes into account existing political incentives for promoting renewable energy but assumes further reforms of the power and gas sector and environmental policies as well as a liberalisation of the transboundary electricity market. The "moderate" GP scenario considers all globally existing and planned political measures for the promotion of renewable energy. It assumes that most countries comply with their national objectives for an expansion of renewable energy and that the international community agrees on an ambitious climate regime which encourages CSP investments. The "ambitious" GP scenario shows CSP deployment under optimal framework conditions. It assumes that political decision-makers fully implement recommendations of industrial stakeholders for the promotion of renewable energies. This includes a ramp up of grid capacities for transmitting power from CSP facilities in the "sunbelt" region to centres of demand in industrialised countries.

Figure 8 Greenpeace Scenarios in Comparison with CSP Deployment Scenarios of the EU-NEEDS Study (Greenpeace et al., 2009; Viebahn et al., 2008)

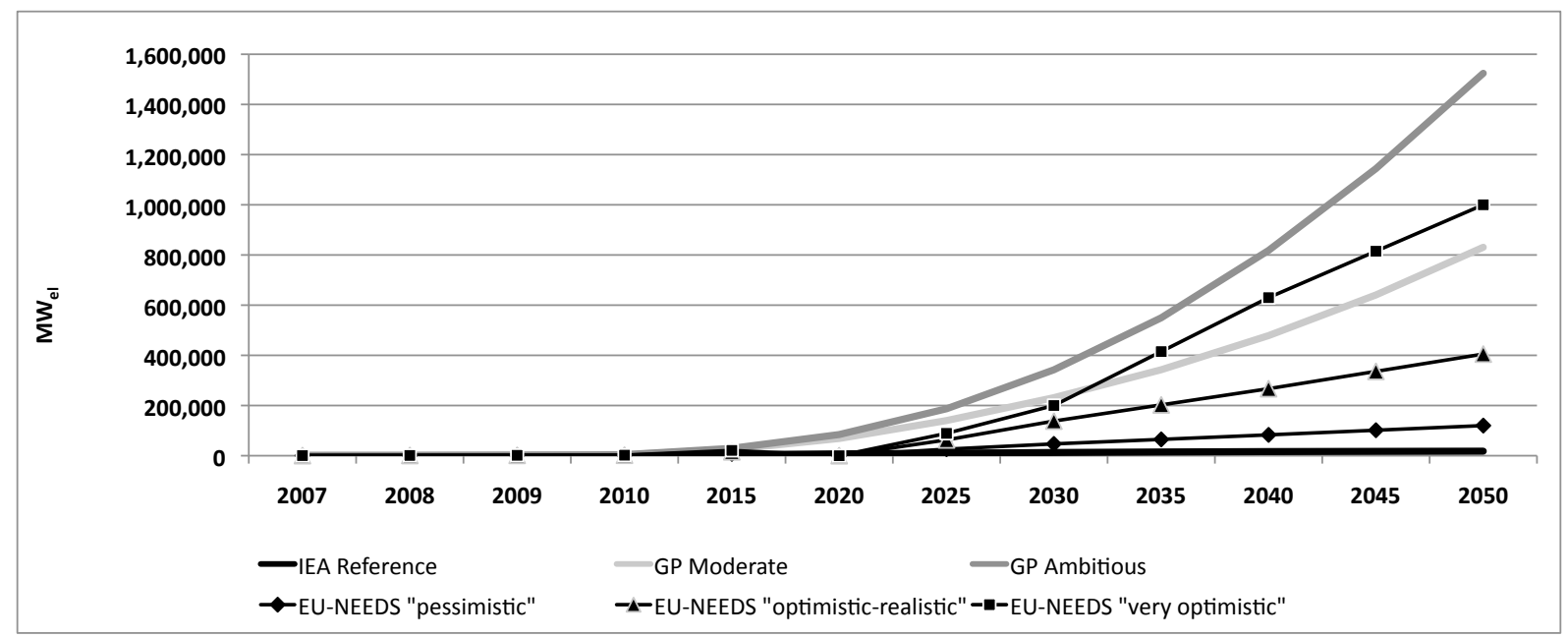

Figure 8 compares the described deployment scenarios with scenarios of the EU NEEDS project (Viebahn et al., 2008). The latter are based on a review of several mid- to long-term 
scenarios and imply both "pessimistic", "optimistic-realistic" and "very optimistic" assumptions. By 2050, the installed CSP capacity in the "moderate" GP scenario is about twice as high as in the "optimistic-realistic" scenario of the NEEDS project; the results of the "ambitious" GP scenario supersede those of the "very optimistic" NEEDS scenario by approximately $50 \%$. The gap between both scenario groups suggests that strong momentum, especially in the period 2025/2030, is required to achieve a massive CSP deployment as assumed in the GP scenarios. In case the substantial cost reduction potentials of CSP technologies could be reaped at this early stage of the scenarios, deployment would accelerate in the decades from 2030.

The IPCC will publish a Special Report "Renewable Energy Sources and Climate Change Mitigation" in 2010 which aims to analyse the potential of renewable energy technologies. The Report will contain scenario analysis of CSP technologies. A comparison of the upcoming scenarios with the presented scenarios might be an interesting starting point for further research. Current IPCC reports on mitigation do not include a detailed analysis of CSP market potentials.

\subsection{Cost Scenarios}

In a first step, the annual investment costs of future power plants need to be defined until 2050. Based on this information, the total investment required for a global ramp up of CSP capacities in the coming four decades and the economic benefits of German technology companies resulting from these investments can be determined. This paper is based on learning ratios which were developed in the European NEEDS project for solar thermal power plants (Viebahn et al., 2008). Due to differing levels of maturity of each CSP process stage, different learning ratios are applied for key plant components (see table 3). While the conventional power generating block is widely mature and merely needs to be adapted to the specific characteristics of a CSP plant, other components such as the solar field or the thermal storage imply a significant potential for cost reductions.

Table 3 Learning Ratios for CSP Key Components (Viebahn et al., 2008)

\begin{tabular}{lcclc}
\hline Component & $\begin{array}{c}\text { Learning } \\
\text { Ratio }\end{array}$ & Progress Ratio & Unit & $\begin{array}{c}\text { Marginal } \\
\text { Costs }\end{array}$ \\
\hline Collector Field & $12 \%$ & $88 \%$ & $\mathrm{~m}^{2}$ Aperture & -- \\
Thermal Storage & $12 \%$ & $88 \%$ & $\mathrm{kWhel}_{\text {Storage Capacity }}$ & --- \\
Conv. Power Block & $5 \%$ & $95 \%$ & $\mathrm{~kW}$ el Capacity & $800 € / \mathrm{kW}$ \\
Labour, Commissioning etc. & $0 \%$ & $100 \%$ & $\mathrm{~kW}$ el Capacity &
\end{tabular}

The specific CSP investment costs $\left(€ 6,000 / \mathrm{kW}_{\mathrm{el}}\right)$ presented in Table 2 are used as a starting point for the cost analysis. The assumed investment costs are rather high compared to assumptions of other studies such as the 2009 Greenpeace report $\left(€ 4,000 / \mathrm{kW}_{\mathrm{el}}\right)$. The gap may be explained by the fact that this paper explicitly takes into account costs of a thermal storage system with a storage capacity of 7.5 hours and therefore a solar multiple ${ }^{2}$ of 2 . The factor has been included as the operation of a thermal storage enables CSP plants to offer "power on demand", which is an outstanding advantage of CSP: Currently, both hybrid power plants (combined solar and gas/coal turbines) as well as solar-only CSP plants are being built to foster the technological development and the cost decrease potential. Due to increasing fossil

2 The solar multiple (SM) indicates, how much collector fields of full power are used. A power plant without storage has a SM of 1, whereas a power plant with a 7.5 hour storage needs two solar fields - one for the regular operation, one for filling the storage $(\mathrm{SM}=2)$. 
fuel prices and decreasing CSP cost, in the future mainly solar-only CSP plants will be used which are predestinated for "power on demand".

This increases the total investment costs by $2,000 € / \mathrm{kW}_{\mathrm{el}}$ since it requires the storage system by itself plus a second collector field only for loading the storage. The Greenpeace report seems to consider power plants with a solar multiple between 1.1 and 1.3 which means only very low storage capacity. In the future, both cost curves converge since the Greenpeace report assumes increasing storage capacity resulting in a capacity factor of $50 \%$ (moderate) and 59\% (ambitious scenario) in 2050.

Costs for labour, commissioning etc. are not included in the presented learning curve but are considered as a constant factor. This is due to the assumption that possible learning effects on these fields would be most likely offset by increasing fees or salaries.

Further limitations of the analysis need to be taken into account:

- The learning curves do not include varying learning ratios for the analysed scenario period.

- The learning ratios of the solar field and the thermal storage are derived from the SEGS plants in California whose total capacity $\left(354 \mathrm{MW}_{\mathrm{el}}\right)$ is a rather limited basis for a learning curve analysis.

- The cost analysis is based on cost data from 2009; future economic developments, such as inflation, changing prices etc., are not taken into account.

- The analysis is limited to parabolic trough plants and should be extended to solar tower plants in a follow-up study.

Figure 9 exemplifies the cost development of CSP key components as well as the overall plant costs in the "moderate" GP scenario. It becomes clear that the most significant reduction of investment costs occurs in the coming ten years due to substantial capacity additions at the beginning of the scenario period.

Figure 9 Development of CSP Investment Costs in the "Moderate" GP Scenario According to the Learning Curve Approach (Own Calculation)

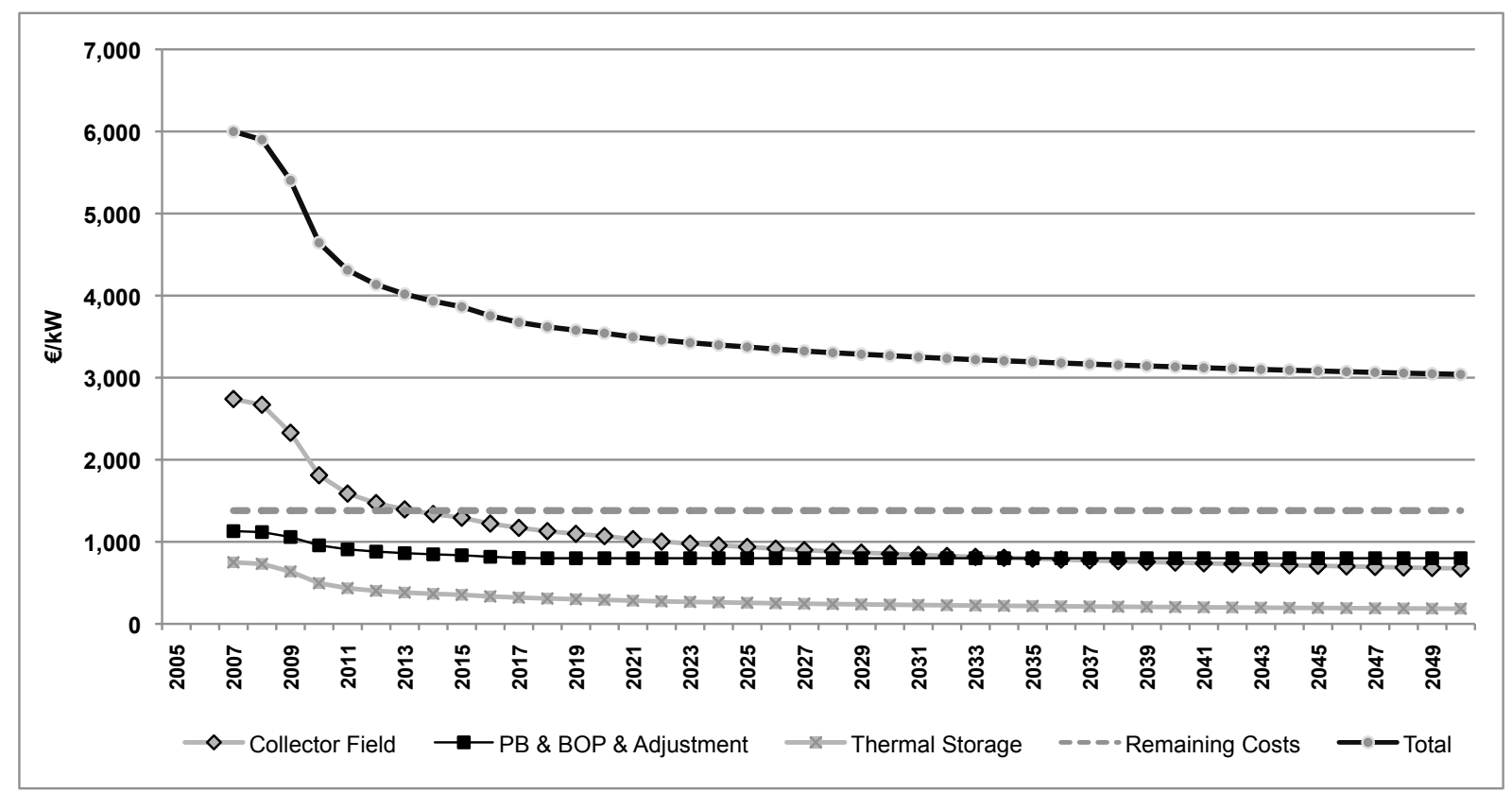

Figure 10 summarises the cost development of CSP plants in the IEA reference scenario as well as the "moderate" and "ambitious" GP scenarios. While in the reference scenario CSP 
investment costs decrease from $€ 6,000 / \mathrm{kW}_{\text {el }}$ to $€ 4,000 / \mathrm{kW}_{\mathrm{el}}$, the Greenpeace report expects a cost reduction to approximately $€ 3,000 / \mathrm{kW}_{\mathrm{el}}$. The cost curves of the "moderate" and the "ambitious" GP scenario follow a rather similar course due to a strong growth and therefore fast doublings of installed CSP capacities at the beginning of each scenario.

Figure 10 CSP Investment Costs in the IEA Reference Scenario, the "Moderate" and "Ambitious" GP Scenarios (Own Calculation)

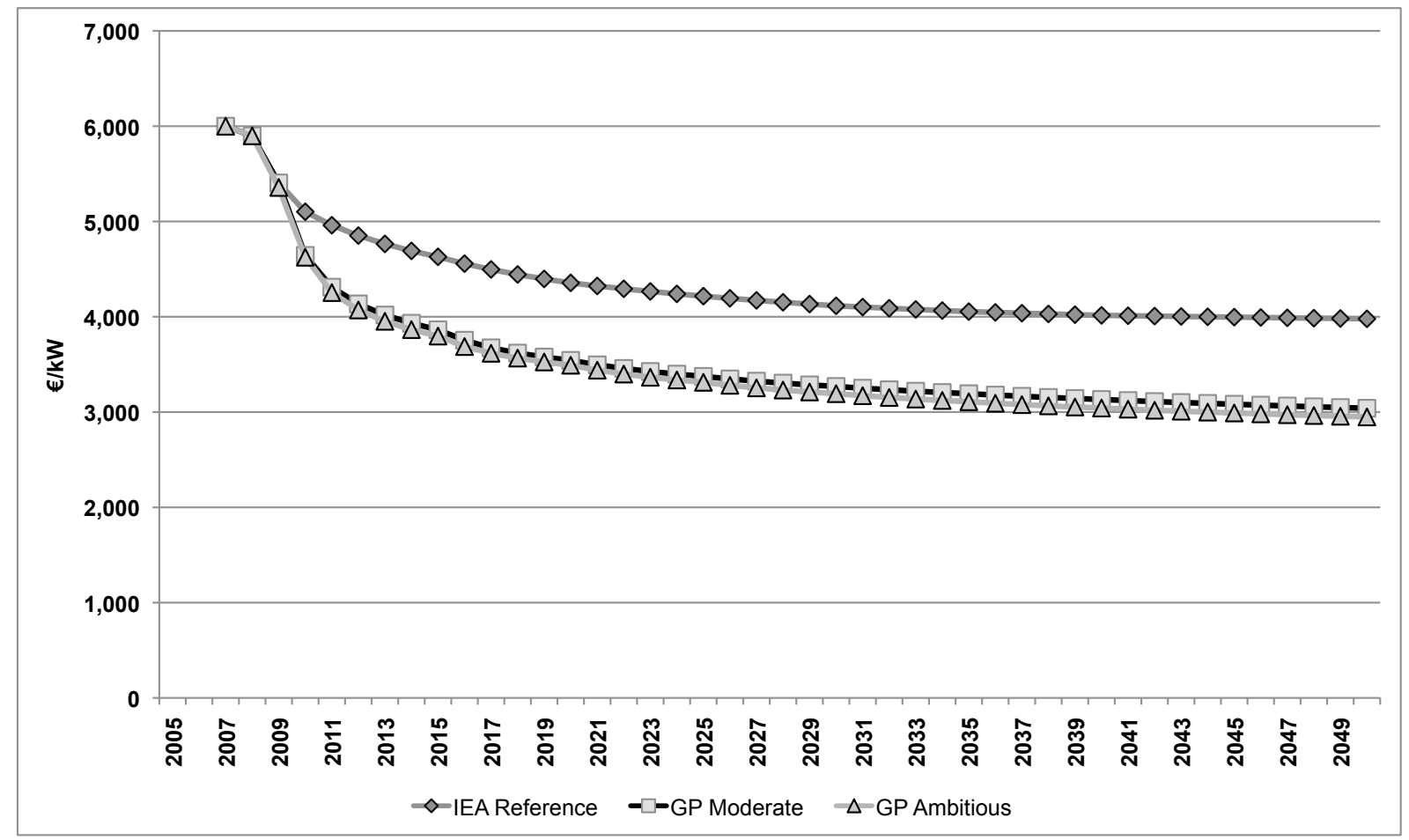

Different from figure 8 which illustrates the total installed capacities of CSP in the three scenario paths, the analysis of the value creation resulting from a global CSP deployment focuses on annual capacity additions and the investments needed for this purpose. Table 4 therefore presents the total investment costs assumed in the three deployment scenarios resulting from capacity additions per decade. 
Table 4 Investment Costs of CSP Capacity Additions per Decade

\begin{tabular}{|c|c|c|c|c|c|c|c|}
\hline IEA Reference & & 2010 & 2011-2020 & 2021-2030 & 2031-2040 & 2041-2050 & Total \\
\hline Added Capacity & GW & 1.67 & 6 & 5 & 4 & 2 & 18 \\
\hline Collector Field & $€$ Mill & 3,549 & 9,057 & 8,012 & 5,089 & 2,187 & 27,894 \\
\hline PB \& BOP \& Adjustment & $€$ Mill & 1,706 & 5,121 & 4,820 & 3,148 & 1,367 & 16,162 \\
\hline Thermal Storage & $€$ Mill & 972 & 2,479 & 2,193 & 1,393 & 599 & 7,636 \\
\hline Remaining Costs & $€$ Mill & 2,309 & 7,725 & 7,582 & 5,044 & 2,205 & 24,865 \\
\hline Total & $€$ Bill & 9 & 24 & 23 & 15 & 6 & 77 \\
\hline GP Moderate & & 2010 & 2011-2020 & 2021-2030 & 2031-2040 & 2041-2050 & Total \\
\hline Added Capacity & GW & 3.95 & 65 & 163 & 247 & 352 & 831 \\
\hline Collector Field & $€$ Mill. & 7,145 & 69,136 & 139,106 & 184,850 & 237,723 & 637,961 \\
\hline PB \& BOP \& Adjustment & $€$ Mill. & 3,776 & 51,711 & 130,198 & 197,840 & 281,660 & 665,185 \\
\hline Thermal Storage & $€$ Mill. & 1,956 & 18,925 & 38,079 & 50,601 & 65,075 & 174,637 \\
\hline Remaining Costs & $€$ Mill. & 5,444 & 89,202 & 224,592 & 341,274 & 485,864 & $1,146,376$ \\
\hline Total & $€$ Bill & 18 & 229 & 532 & 775 & 1,070 & 2,624 \\
\hline GP Ambitious & & 2010 & 2011-2020 & 2021-2030 & 2031-2040 & 2041-2050 & Total \\
\hline Added Capacity & GW & 4 & 80 & 258 & 476 & 706 & 1524 \\
\hline Collector Field & $€$ Mill & 7,373 & 82,608 & 205,120 & 322,219 & 426,210 & $1,043,529$ \\
\hline PB \& BOP \& Adjustment & $€$ Mill & 3,913 & 64,189 & 206,372 & 380,705 & 564,792 & $1,219,970$ \\
\hline Thermal Storage & $€$ Mill & 2,018 & 22,613 & 56,150 & 88,205 & 116,672 & 285,658 \\
\hline Remaining Costs & $€$ Mill & 5,658 & 110,726 & 355,992 & 656,716 & 974,266 & $2,103,357$ \\
\hline Total & $€$ Bill & 19 & 280 & 824 & 1,448 & 2,082 & 4,653 \\
\hline
\end{tabular}

\subsection{Value-Added Scenarios}

\subsubsection{German Participation in the Reference Plant}

Based on current human resources, production capacities and expertise, Kistner calculated that German companies could cover approximately 33\% of the EPC (engineering, procurement, construction) price of a typical parabolic trough plant (Kistner, 2009). If framework conditions deteriorate, the German portion in the valued-added chain would decline to $10 \%$. Such a scenario could occur in case of a lack of financing for German general contractors, a loss of know-how and expertise and increasing standardisation of key components which facilitates their production by other players or in other countries. If German companies succeed in strengthening their competencies and expertise on strategically important fields of technology with high potentials for revenues, their participation in the valued-added chain may grow to $41 \%$.

If German companies participate with a share of $33 \%$ in the value-added chain of the reference CSP plant, 33\% of the generated revenues flow to German market players. Market players are considered as German companies if their headquarters are located in Germany. Due to the limited scope of this study, it was not possible to distinguish between CSP plant components which were manufactured in domestic or international manufacturing units of German market players. 
Table 5 Share of German Companies in the Investment Costs by Plant Components (Own Calculation Based on Kistner, 2009)

\begin{tabular}{lc} 
Component & $\begin{array}{c}\text { German Share of } \\
\text { Components in \% }\end{array}$ \\
\hline Collector Field & 60 \\
HTF System & 41 \\
Thermal Storage & 1 \\
Conv. Power Block & 80 \\
Labour, Engineering, Commissioning & 55 \\
Civil Works & 0
\end{tabular}

Based on 33\% German content in the reference plant, table 5 presents the share of German companies in the investment costs by plant component. It shows that German expertise is particularly high with regard to the solar field, the heat transfer fluid system and the power block.

For the purpose of simplification, figure 11 summarises some of the plant components (e.g. solar field and heat transfer fluid) and puts the German contribution to each component in relation to the total plant investment costs. At total investment costs of $€ 300$ million, a percentage of 33 is equivalent to $€ 99$ million. If the German industry succeeds in strengthening its know-how on strategic fields, its part in value creation could increase to $41 \%$ or $€ 123$ million. If framework conditions deteriorate, the German share shrinks to $10 \%$ or $€$ 30 million.

Figure 11 Share of German Companies per Key Component in Relation to the Total Investment Costs of the Reference Plant (33\% Case) (Own Calculation Based on Kistner, 2009)

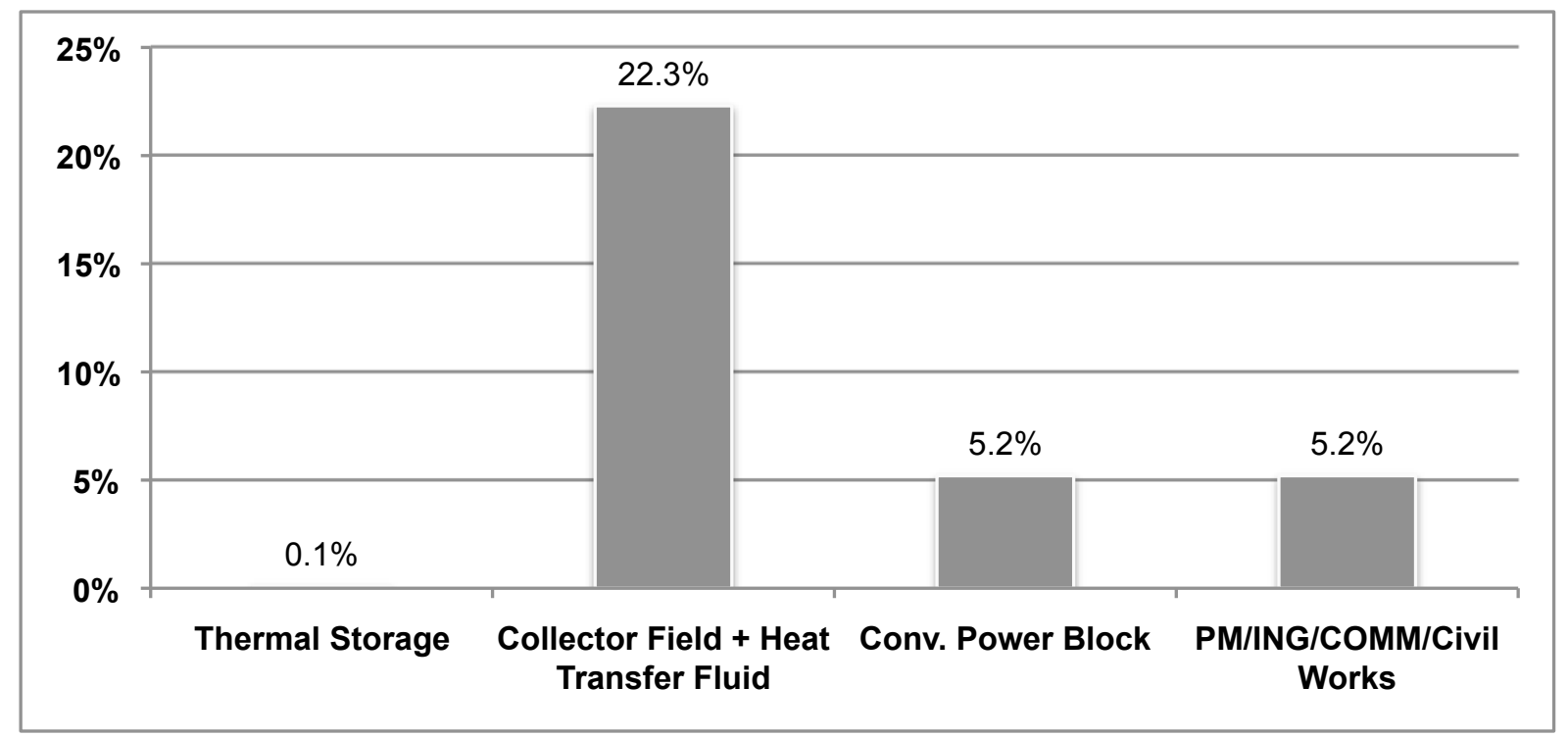




\subsubsection{Economic Benefits for German Companies Resulting from a Global Deployment of CSP}

This section presents a rough estimate of the value creation potential of German companies resulting from a global deployment of CSP technologies based on the technology deployment scenarios, the cost scenarios and specific German shares in value creation. The calculation of the revenues of German companies resulting from a global ramp up of CSP is based on four cases: Three cases constantly apply the German shares assumed by Kistner (10\%, 33\%, 41\%) to the costs of CSP key components. However, as mentioned above, Kistner's analysis does not take into account all elements of plant investment costs and excludes important parameters. Therefore, the fourth case assumes a German valued-added share of $37 \%$. This percentage results if the percentages defined by Kistner per plant component (see table 5) are applied to $100 \%$ of the reference plant investment costs as outlined in table 2 .

The revenues of German market players from 2010 until 2050 are presented in five-year steps reflecting their total revenues from cumulated CSP capacity additions during the considered five-year period. Revenues are presented in five-year steps as capacity additions in the Greenpeace scenarios are also given in five-year periods.

Figure 12 Revenues of German CSP Companies in the IEA Reference Scenario (Own Calculation)

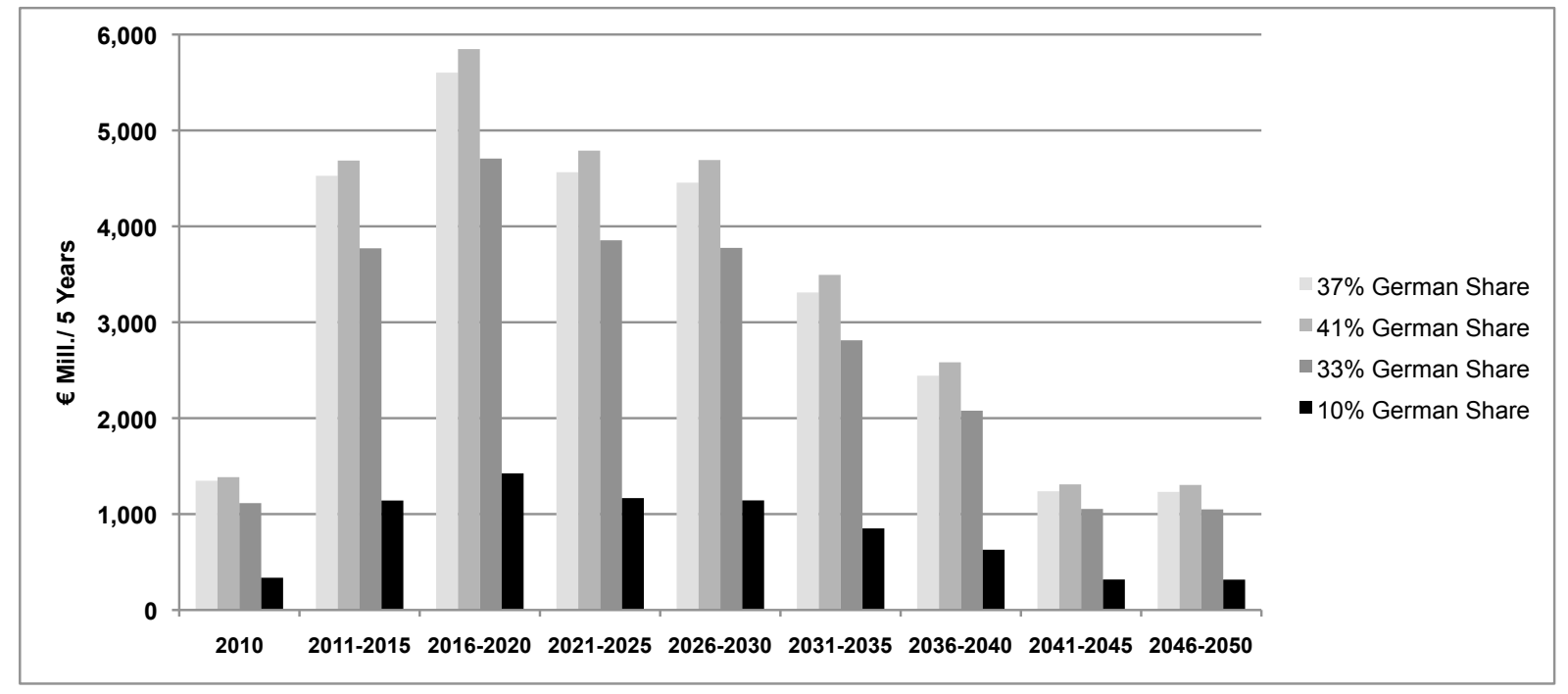

Figure 12 illustrates the participation of German CSP companies in the value creation resulting from CSP deployment as assumed in the IEA reference scenario. Although this scenario projects an increase of total installed CSP capacities until 2050, the amount of annually added generating capacities declines from 2020. As a consequence, the revenues of German technology companies decrease from 2020 to 2050 after a sharp increase at the beginning of the scenario period. Revenues peak at $€ 1.4$ to 5.9 billion in the period from 2016 to 2020 and decline to $€ 0.3$ to 1.3 billion for the five-year period from 2046 to 2050 . 
Figure 13 Revenues of German CSP Companies in the "Moderate" GP Scenario (Own Calculation)

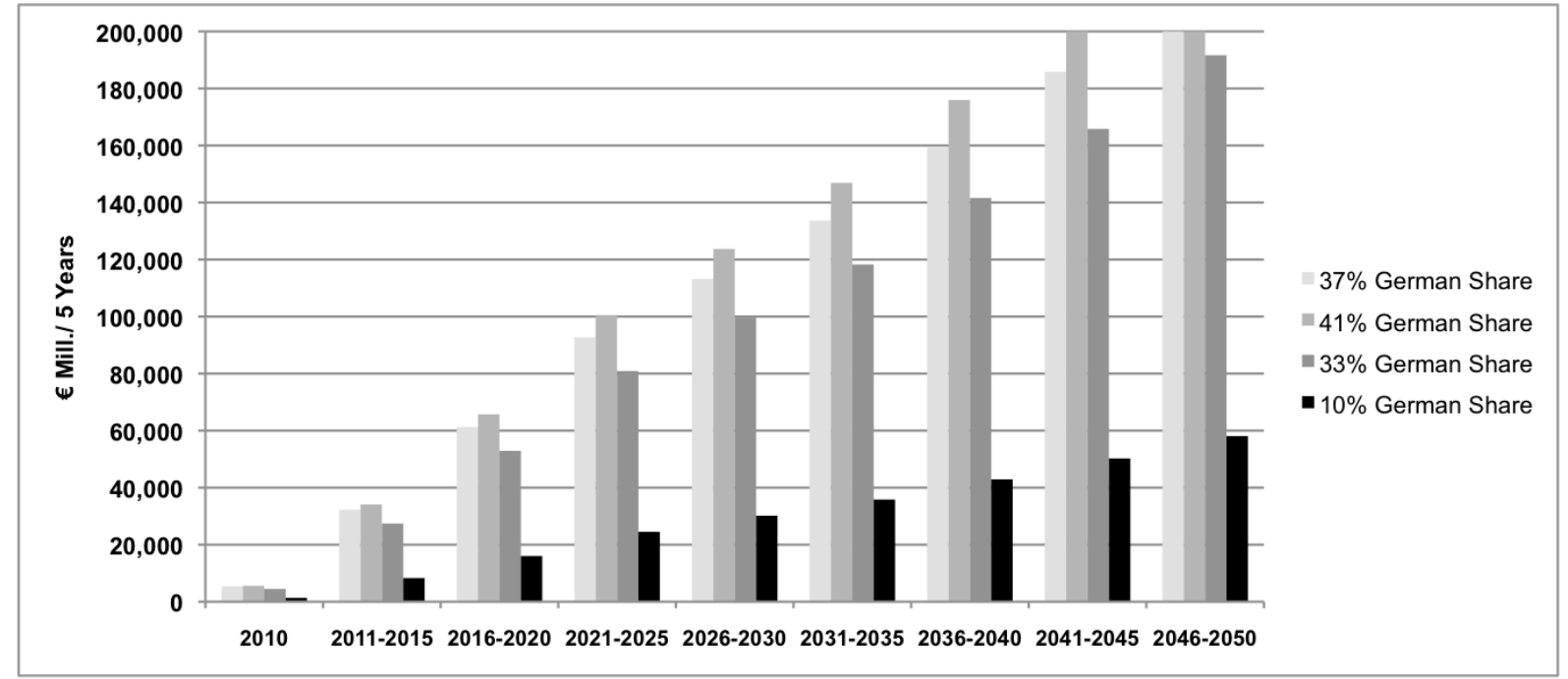

Figure 14 Revenues of German CSP Companies in the "Ambitious" GP Scenario (Own Calculation)

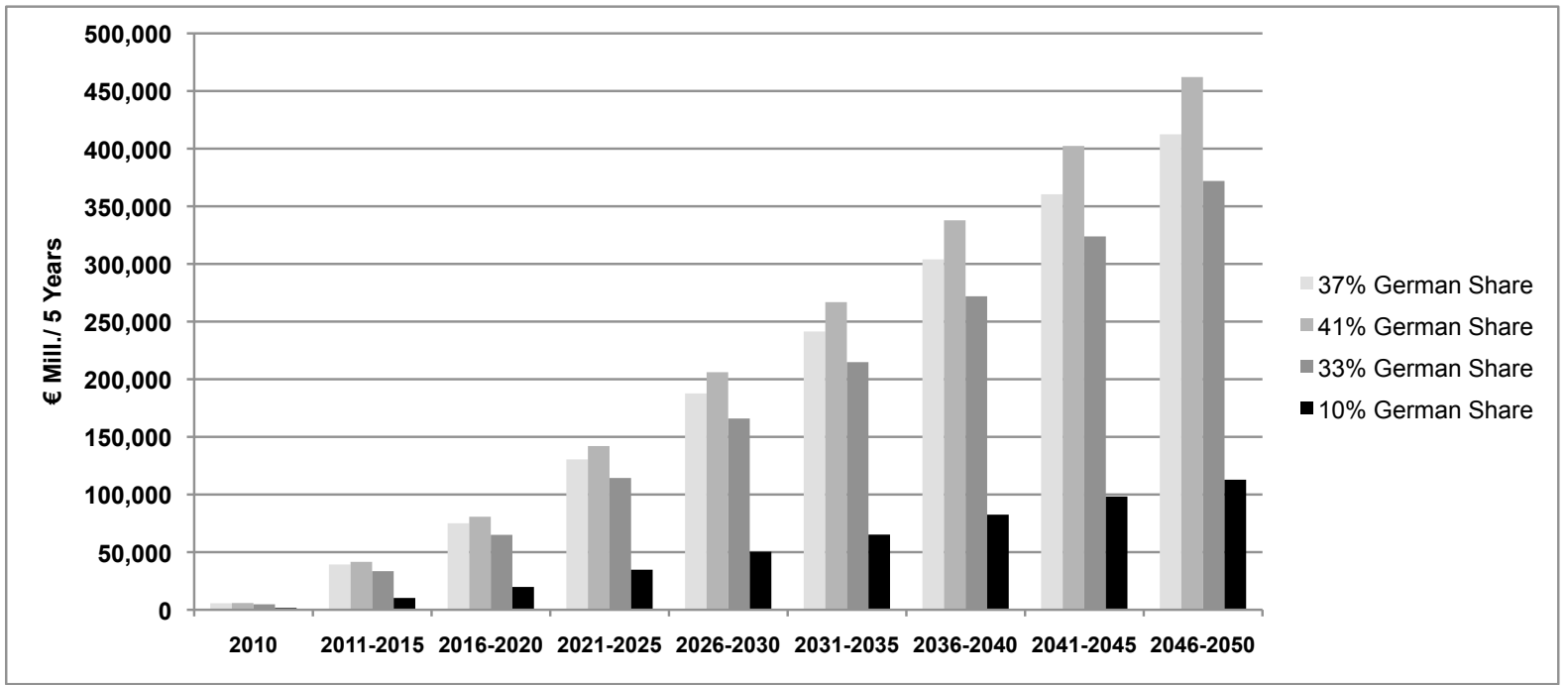

Due to a more dynamic development, the "moderate" and "ambitious" GP scenarios lead to significantly higher and continuously growing revenues for German companies (see figures 13 and 14). In the "moderate" scenario, the development begins with revenues ranging from $€$ 8.4 to 34.4 billion from 2011 to 2015 . At the end of the scenario horizon, it reaches a level of $€ 58.3$ to 239.1 billion (2046-2050). In the "ambitious" scenario, revenues add up to $€ 10.2$ to 41.7 billion from $2011-2015$ and increase to $€ 113.1$ to 463.7 billion in the period from 20462050 . 
Figure 15 Cumulative Revenues of German Companies in the Considered Scenarios (Own Calculation)

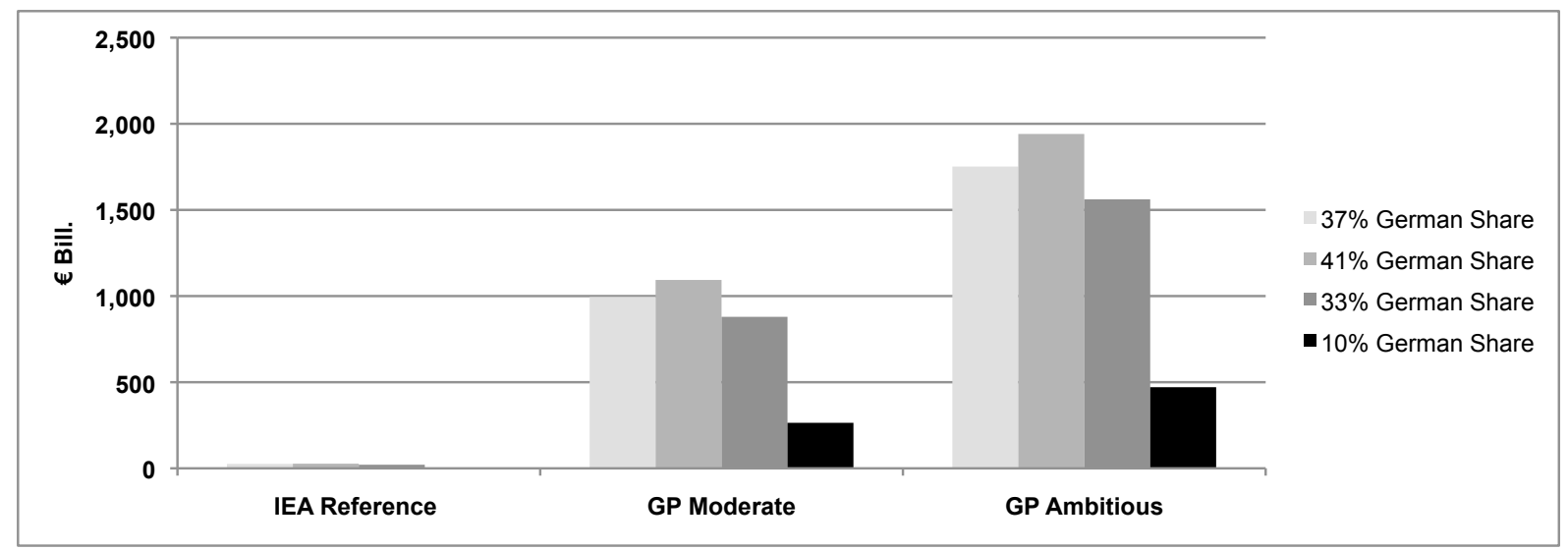

Figure 15 summarises the cumulated potential value creation of German companies in the period from 2010 to 2050 . Their revenues range from $€ 7$ to 30 billion in the reference scenario, $€ 269$ to 1,102 billion in the "moderate" GP scenario and $€ 476$ to 1,952 billion in the "ambitious" GP scenario.

These figures seem to be very high but represent only a minor share of the overall investments in the energy sector needed in the coming decades. In the reference scenario of the 2008 Energy Technology Perspectives report (IEA, 2008), the International Energy Agency projects that until 2050, a total investment of approximately $€ 182$ trillion ( $\$ 254$ trillion) is required in order to satisfy increasing global energy demand. This amount would be equivalent to approximately $6 \%$ of the global GDP in the same period.

The power plant sector represents about $5 \%$ or $€ 9.1$ trillion ( $\$ 12.7$ trillion) of the total energy investments needed (IEA, 2008). Consequently, the cumulated revenues of German companies resulting from international CSP deployment represent only a small portion of global investments in the energy sector until 2050. However, due to the recent economic downturn, it is widely expected that actual investments in the power sector will not meet the projections of the IEA report. Thus, estimates on future power plant investments imply a high degree of uncertainty.

\section{Conclusions and Need for Further Research}

Our main conclusion is that the German CSP industry is well-positioned on the international market. This is particularly true for highly specialised component suppliers such as Schott Solar or Flagbeg. General contractors, such as Solar Millennium, have been or are involved in existing or planned CSP plants but are not among the major players on the international market which is dominated by Spanish and U.S. companies. Thus, a further expansion of specialised know-how and expertise on the fields of key CSP components with high strategic relevance and high potential returns offers the greatest opportunity to increase the German share of the CSP market.

However, in order to meet the projected demand for CSP technologies or components, German market players need to ramp up their manufacturing capacities. For example, Siemens recently expanded its capacities for the production of solar thermal steam turbines. At the time being, however, manufacturing capacities of most CSP technology providers are limited. Investments in manufacturing capacities would most likely pay off very well since the global expansion of CSP capacities in the considered scenarios would generate an enormous value creation potential for German technology providers. Furthermore, an 
appropriate German industrial policy is required to remain one of the main players on the global CSP market and to face the risk of falling back to the $10 \%$ scenario considered by Kistner (2009).

The following elements could be important cornerstones of an effective industrial policy for CSP promotion: a) Increasing support for research and development activities with specific on key components with high German expertise; b) strengthening the education of CSP-related know-how at universities or technical colleges; c) providing incentives for the demonstration of CSP technologies in order to pave the way for technology exports; d) building bilateral partnerships or platforms with key countries for CSP promotion, especially countries in the MENA region.

The study reveals need for further research with regard to the following aspects:

The presented analysis of the German participation in the CSP value-added chain is merely a first attempt to roughly estimate potential revenues for the industry resulting from a global deployment of CSP. In order to generate more precise data, an in-depth assessment of German know-how, expertise and capacities - both manufacturing capacities, financial and human resources - on the CSP sector is needed. Furthermore, it should be distinguished between value creation of German companies which is realised in domestic and international production units. For that purpose, it would be helpful to expand the research perspective from a national level to other relevant world regions in order to take into account the specific framework conditions (stakeholder constellations, policy setting, production conditions) in these regions. Last but not least, the analysis should not remain limited to the parabolic trough technology but integrate other CSP technologies, especially the solar tower technology.

\section{References}

Ausra, 2010. Solar. AREVA Completes Acquisition of U.S. Solar Company Ausra. Press release from March 2, Mountain View.

BINE Information Service, 2003. Solarthermische Kraftwerke, Projektinfo 12/03, Bonn.

Christmann, Ralf, 2009. BMU Research Funding in the Field of Concentrating Solar Power. Presentation on the forum „CSP Now!“ at the Hannover Exhibition on April 20, 2009.

ESTELA (European Solar Thermal Electricity Association), 2009. Tower Technology, http://www.estelasolar.eu/index.php?id=29, downloaded on May 25, 2009..

EU (European Union), 2009. Directive 2009/28/EC of the European Parliament and of the Council of 23 April 2009 on the promotion of the use of energy from renewable sources and amending and subsequently repealing Directives 2001/77/EC and 2003/30/EC.

Flabeg, 2009. Track Record Solar Mirrors 1983-2010, Nürnberg.

Geyer, Michael; Mancini, Thomas, 2006. From Research to CSP Market Introduction. Progress and Advances of Concentrating Solar Power $\quad$ Technologies; http://www.tvworldwide.com/events/eqtv/061016/ppt/Michael\%20Geyer.pdf, downloaded on May 24, 2009.

Greenpeace International; EREC (European Renewable Energy Council), 2008. Energy[R]evolution: A Sustainable World Energy Outlook. Amsterdam. http://www.energyblueprint.info/

Greenpeace International; Solar Paces; ESTELA (European Solar Thermal Electricity Association), 2009. Global Concentrating Solar Power: Outlook 09. Why Renewable Energy is Hot. Amsterdam.

IEA (International Energy Agency), 2008. Energy Technology Perspectives 2008. Scenarios \& Strategies to 2050, Paris. 
IPCC (Intergovernmental Panel on Climate Change), 2007. Climate Change 2007: The Physical Science Basis. Contribution of Working Group I to the Fourth Assessment Report of the Intergovernmental Panel on Climate Change [Solomon, S., D. Qin, M. Manning, Z. Chen, M. Marquis, K.B. Averyt, M.Tignor and H.L. Miller (eds.)]. Cambridge

Kistner, Rainer, 2009. German Participation in the Value-Added Chain of CSP-Plant Construction. Presentation on the forum "CSP Now!" at the Hannover Exhibition on April 20, 2009.

Knies, Gerhard, 2009. How industry can make big business with clean power from deserts for a world with 10 billion people? Presentation of the DESERTEC foundation on the forum „CSP Now!“ at the Hannover Exhibition on April 20, 2009.

Neij, Lena, 2003. Experience Curves: A Tool for Energy Policy Assessment, Lund University, European Commission, Lund.

Sarasin (2009). Solarwirtschaft - grüne Erholung in Sicht. Technologien, Märkte und Unternehmen im Vergleich, Basel.

Schott Solar, 2008. Geschäftsbericht 2007/2008, Mainz.

Selig, Martin, 2009. First CSP Plant Based on Nova-1 Fresnel Collector Technology in Operation Experiences and Outlook. Presentationon the forum "CSP Now!" at the Hannover Exhibition on April 20, 2009.

SES (Stirling Energy Systems), 2009. http://www.stirlingenergy.com/projects/solar-one.asp, downloaded on May 25, 2009.

Siemens AG, 2008. Steam Turbines for Solar Thermal Power Plants. Industrial Steam Turbines, Erlangen.

Siemens AG Energy Sector 2009. Email from Mrs. Katja Riebisch on December 18, 2009.

Viebahn Peter; Kronshage, Stefan; Trieb Franz; Lechon Yolanda, 2008. Final Report on Technical Data, Costs, and Life Cycle Inventories of Solar Thermal Power Plants. Deliverable 12.2 - RS I a of EU IP-NEEDS. www.needs-project.org . 